\title{
RESEARCH
}

Open Access

\section{Prioritizing dimensions of entrepreneurial ecosystem: a proposed framework}

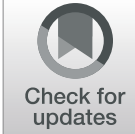

Saeed Mujahid ${ }^{1}$, Shujaat Mubarik ${ }^{1 *}$ and Navaz Naghavi

\author{
* Correspondence: Shujaat. \\ mubarak@jinnah.edu \\ 'Department of Management \\ Sciences, Mohammad Ali Jinnah \\ University, Karachi, Pakistan \\ Full list of author information is \\ available at the end of the article
}

\begin{abstract}
The objective of this study is to prioritize the various dimensions of an entrepreneurial ecosystem (EES) and propose a framework for developing it. The study adopted a threefold approach to meet the objective. First, we extracted 63 dimensions of the entrepreneurial ecosystem through a comprehensive literature review. Second, the extracted dimensions were then shortlisted by focusing on the importance of each in the entrepreneurial ecosystem. Thirty-one selected dimensions were grouped in eight core dimensions, namely markets, finance, human resource development, support, government role, infrastructure, industrial network relationship, and mentorship. Third, the study applied the analytical hierarchy process to prioritize the selected dimensions and sub-dimensions of EES. Data was collected from experts using a bi-polar questionnaire. Results of pairwise comparisons reveal that human resource development possessed the highest weight, followed by finance, support, and industrial relationship. Markets emerged as the least important dimension. The proposed EES provides a basic framework that can be replicated in a specific area to identify the industry-related EES framework.

Keywords: Entrepreneurial ecosystem, Business environment, Business support, Analytical hierarchal process
\end{abstract}

\section{Introduction}

Entrepreneurship has become imperative for the sustained growth and development of organizations across industries. The only global phenomenon and order of the day in the twenty-first century is entrepreneurship, as it has the power to propel the economic growth of countries (Valliere \& Peterson, 2009) and has become as much a social as an economic phenomenon across the globe. It is essential to have a sound entrepreneurship ecosystem (EES) that helps entrepreneurs transform existing firms to exploit new opportunities (Etzkowitz, Webster, Gebhardt, \& Terra, 2000). According to Prahalad (2005), an entrepreneurial ecosystem is composed of humans, entrepreneurship, and society. Entrepreneurship growth in today's complex environment requires cohesive support from numerous players active within a society (Wiklund, Davidsson, \& Delmar, 2008). Earlier entrepreneurial research emphasized the human entrepreneurial factors, predominantly personality traits and skills (Frank, Lueger, \& Korunka, 2007; Korunka, Frank, Lueger, \& Mugler, 2003; Lehner \& Harrer, 2019), neglecting the outside sphere, i.e., entrepreneurship ecosystem (EES). Nevertheless, EES has a significant impact on shaping the

(c) The Author(s). 2019 Open Access This article is distributed under the terms of the Creative Commons Attribution 4.0 International License (http://creativecommons.org/licenses/by/4.0/), which permits unrestricted use, distribution, and reproduction in any medium, provided you give appropriate credit to the original author(s) and the source, provide a link to the Creative Commons license, and indicate if changes were made. 
entrepreneur's evaluation of prospects that can potentially be realized with the new venture. Hence, entrepreneurial decisions are inevitably dependent on how individuals judge their entrepreneurial ecosystem. Although previous studies have shown a positive effect on fundamental decisions in the context of founding a new venture (e.g., Ivanov \& Dolgui, 2018; Suresh \& Ramraj, 2012), research exists on the prioritization of individual components of EES. It is essential to analyze the relative contribution of these factors in order to devise the optimal entrepreneurial promotion policy. While extensive efforts have been focused in developed countries (DCs) like Singapore, Australia, and Europe, there exists a vast gap in less developed countries (LDCs). For example, in Pakistan, it is hard to define the contribution of various elements of the entrepreneurial ecosystem (Williams \& Shahid, 2016). Therefore, it remains pivotal to prioritize the components of EES to develop an effective EES. This study undertakes this task by using Pakistan as a case. In Pakistan, due to the lack of backing from the government, entrepreneurs mostly rely on the support of peers to bring their idea from the drawing board to the real world (Anwar ul Haq, Usman, Hussain, \& Anjum, 2014). The situation has worsened due to globalization. Entrepreneurs in Pakistan find it difficult to survive in a competitive global environment. This requires assessing the relative importance of the factors forming EES and stressing the highly prioritized dimensions of EES to promote entrepreneurship in Pakistan (Anwar ul Haq et al., 2014). In this context, the overarching objective of the study is to identify, select, and prioritize the entrepreneurial ecosystem relevant for entrepreneurs operating in Pakistan. The study adopts a threefold approach in order to delineate the factors which are highly relevant in the context of Pakistan. Likewise, the study uses the analytical hierarchy process (AHP) for quantifying the subjective judgment of the selected experts.

\section{Entrepreneurial ecosystem: definitions and dimensions}

Entrepreneurs are heterogeneous; thus researchers classify them by their attributes, such as demography, business strategies, and psychographs. Smith (1967) introduced the term "craftsman entrepreneur" for those coming from a blue-collar background, with less education, and lacking management experience. He named the other type "opportunistic entrepreneurs," those with educations and diverse management experience, having access to multiple sources of financing and looking for new opportunities. The latter type of entrepreneurs has a higher growth rate because of their ability to better understand the business environment, according to Smith and Miner (1983). Campbell (1992) tied the probability of an entrepreneur's success, whether opportunistic or craftsman, to the external environment, later known as EES. These studies, among many others, proclaimed that external environment has a higher influence on the survivability, profitability, and scalability of any entrepreneurial ventures. On the same note, Man, Lau, and Chan (2002) suggested that three factors nurturing the success of an enterprise were its internal factors, the entrepreneur, and the environment in which it is working. Elaborating the external impact, Bygrave, Hay, Ng, and Reynolds (2003) mentioned that external entrepreneurial culture affected the intensity of new entrepreneurial ventures. Categorizing external entrepreneurial culture into favorable and unfavorable, they mentioned that favorable environmental factors considerably motivated individuals to undertake an entrepreneurial venture. The intention to start a new 
business is influenced by an individual's perception about its feasibility and desirability, which is partially due to one's understanding and knowledge of environmental factors. Afterward, entrepreneurs use their abilities and skills to craft a space for themselves in a given environment to look for the opportunity that matches their personality traits (Shapero \& Sokol, 1982). Likewise, Segura (1988) suggested that the need for an entrepreneur-friendly environment is greater in developing countries and emerging economies because entrepreneurs in these economies are mostly working in a hostile situation. Further, Oosterbeek, Van Praag, and Ijsselstein (2010) emphasized the need for entrepreneurial-friendly policies to develop an entrepreneurial support system, while Shapero and Sokol (1982) asserted that social and cultural environments also affect individuals' intentions to become entrepreneurs.

Researchers (Allesina, Azzi, Battini, \& Regattieri, 2010; Ivanov \& Dolgui, 2018) and policy advisers argue that networks of interconnected firms play a pivotal role in equipping firms with a competitive advantage. Therefore, entrepreneurs are looking toward their ecosystem in order to achieve success for themselves. That is why entrepreneurship is collaborating with their ecosystem to gain distinctive capabilities. Studies (e.g., Allesina, Azzi, Battini \& Regattieri, 2010; Lehner \& Harrer, 2019) argued that the external environment is the primary source of opportunities for all types and sizes of businesses. Thus, for successful entrepreneurial ventures both internal factors in terms of entrepreneurs and the capacity and expertise to run an enterprise and external factors, EES, matter equally. Abid (2007) stated that besides entrepreneurial capabilities and intentions, the conducive EES of the USA helps to promote new startups with immense economic contributions.

Despite recurring discussion on the external environment and its importance, the term EES was first formalized by Cohen (2006). He mentioned it as an integration of various players of a community, to facilitate and support entrepreneurs for sustainable growth. This integration synergizes the activities performed by these community players, and it results in creating value for its stakeholders. Although stakeholders are motivated by their unique requirements and objectives, an active ecosystem synergizes their efforts in the right direction. Thereby an ecosystem can be instrumental in the growth of a stable economy, while it plays the role of rescuer in the case of less developed economies. An entrepreneurial ecosystem also entails the harmonization of entrepreneurship and intentional thoughts in a way that will create knowledge to support new enterprise (Iansiti \& Levien, 2004; Lee \& Peterson, 2000). Below, we briefly delineate the factors acting as the components of an entrepreneurial ecosystem.

\section{Components of an entrepreneurship ecosystem}

Researchers define an entrepreneurial ecosystem as a composition of coordinated and mutually dependent factors that result in the formation of a creative environment for entrepreneurship in a country. Isenberg (2010) listed thirteen elements serving as major dimensions of an entrepreneurial ecosystem: culture, capital, education, government, human resources, economic clusters, infrastructure, leadership, networks, support services, success stories, and early customers. In addition to these factors, some researchers (e.g., Fellnhofer \& Mueller, 2018; Kautonen, Van Gelderen, \& Fink, 2015; Krueger, 2017; Lehner \& Harrer, 2019) consider government, media, and institutions 
(educational and financial) as essential stakeholders in EES. Likewise, culture appears almost in every study of EES as the crucial determinant of EES. It provides a social status to an entrepreneur. It tolerates their failure so that they can test their creativeness and innovativeness. A culture where entrepreneurship is encouraged and supported by moral or physical assistance is one that nurtures entrepreneurial venture. According to Mokry (1988), local communities and individuals from communities help entrepreneurs in establishing their businesses, seeking a solution to their problem, locating resources, and preparing a team of dedicated persons for an enterprise. If society values entrepreneurs, then it will be a great support in the development of social systems that admire them (Vesper, 1983). Nevertheless, these are not the only factors comprising EES, and numerous factors have appeared in research as the essential component of EES. What follows is a discussion of the factors which are accepted as pillars of EES by a majority of studies.

\section{Finance}

This represents the available financial assistance structure in a society. It shows the degree to which an entrepreneur can have access to formal or informal funds to start a venture. These fund providers can be angel investors, private equity funds, commercial banks, microfinance institutions, NGOs, or governmental institutions like the Small and Medium Enterprises Development Authority (SMEDA) in Pakistan (Mubarik, Chandran, \& Devadason, 2018; Naghavi \& Mubarak, 2019). In short, these creditors are the major constituents of the financial assistance structure of an EES.

\section{Human resource development}

These are the planned initiatives aimed at enhancing the skills required to undertake or boost entrepreneurial ventures. These skills are harnessed through various training activities like on-the-job training, vocational training, and industrial training. The government or other stakeholders conduct such activities through planned efforts to promote specific entrepreneurship in society. The societies having such planned initiatives tend to promote entrepreneurship rapidly as compared to others (Krueger, 2017). Further, a strong industry-academia collaboration to develop industry needs to drive human resource development (HRD), and international agencies like UNIDO and USAID can be instrumental in HRD efforts.

\section{Markets}

An encouraging and large market should be comprised of customers, intermediary firms including both suppliers, and distributors help entrepreneurial ventures to promote themselves. The existence of such markets provides a good customer base to these new businesses, as well as suppliers to buy materials or other services. Such markets are deliberately developed in the form of industrial clusters (Mubarik, 2015). These industrial clusters play a significant role in promoting new firms. Likewise, the existence of mega urban centers also has a positive influence on entrepreneurship. Researchers (e.g., Bhawe \& Zahra, 2017) have also noted that it is the marketing efforts which influence entrepreneurial survival, and it is the supply chain which decides its 
long-term stability. Romero-Martínez and Montoro-Sánchez (2008), while studying characteristics of business clusters, concluded that they have a dual role of competition and cooperation. As a consequence of this, they have a more constructive influence on new venture creation. These dual phenomena on the one hand compel them to work hard and increase their access to more inputs, while on the other hand, they serve as a source of information and technology which helps them become more innovative and creative.

\section{Support}

Despite developing good policies, entrepreneurs look for assistance like legal, technical, and financial to undertake their venture. A well-integrated mechanism for providing such assistance can be a more significant source of promoting entrepreneurial ventures, as some businesses could not be developed without such assistance. This assistance can be from non-governmental actors such as business associations supporting them in the development of incubators or from governmental institutions (Nabi, Liñán, Fayolle, Krueger, \& Walmsley, 2017). This support comes as Moral support from parents, siblings, relatives, friends, and other family members in terms of appreciating the entrepreneurial efforts. Social support appears in the form of social respect for entrepreneurs and motivation for those who are in the struggling phase of a venture. Technology support from government or private incubators, availability of technical persons, and most important, the technology itself comes from local educational institutions or is transferred from abroad on terms or conditions. Environmental support is a critical aspect of an entrepreneur's success that is in the shape of natural resources that include both access to and availability of climatic and natural assets (Boyd, Dess, \& Rasheed, 1993).

\section{Governmental role}

Government has two significant roles in promoting entrepreneurship. First is the regulatory role, which is forming the policies for providing a level playing field by ensuring justice. Second is a developmental role, through initiating various programs including HRD, financial assistance, and other types of assistance. These include all governmental policies which help to promote entrepreneurial ventures and safeguard their interests, such as conflict resolution mechanisms, patent policies, laws of taxation, and other business-related regulations. In a conducive EES, such policies are expected to be tailored in favor of entrepreneurs to promote such ventures (Malen \& Marcus 2017). The government must make laws to protect intellectual property rights. In some countries, the government has gone out of the way to promote entrepreneurship. One such example is Australia where the Australian government, in order to promote entrepreneurship in their country, eased immigration restrictions for foreigners with a business idea or experience.

\section{Infrastructure}

Van de Ven (1993) has elaborated that infrastructure is one of the significant factors which restrains or expedites entrepreneurship in an economy. This includes publicresourced endowment funds for the development of scientific knowledge, institutions to 
facilitate and expedite research and development, and effective financial systems for catering to the financial requirements of entrepreneurs. Such infrastructure may also include the incubators to promote entrepreneurship by assisting them in terms of technological adoption, idea enhancement, and knowledge creation. Thus, they increase the entrepreneurs' potential to create value in their deliverables. Rahatullah Khan (2013) studied the ecosystem in Saudi Arabia and recommended that an organized structure is needed to cater to the development requirements of entrepreneurs by providing them with educational institutions that can enhance their professional capabilities and building incubators to provide soft skills. There is a need for collaboration among the different industries. Research culture must be initiated so that it will help improve their products and processes. Consulting firms are required to cater to the financial needs as well as the support needs. The entrepreneurial venture, especially in IT, needs IT infrastructure and buildings. Some entrepreneurs could not afford to have full-blown buildings and IT setups. To support such ventures, the availability of buildings and IT supports can be hugely beneficial. It can be done through incubation centers or as standalone functions.

\section{Industrial relationship networks}

Stuart and Sorenson (2005) urged that networks of individuals and firms not only provide opportunities for new ventures but also help them in managing the restraints they face. Johannisson (2017) has classified three networks, namely, information networks to identify opportunities; to acquire resources, an exchange network is required; and networks of influence for building acceptability so that businesses can get hold of competition. The same point is highlighted by Elfring and Hulsink (2003): Networking at different levels and spheres influences the creation and growth of the firm by keeping track of opportunities and utilization of resources. Similarly, Klyver and Grant (2010) suggested that networking is an essential tool for the growth of an enterprise. Rahatullah (2010) said that networking among entrepreneurial businesses results in the success of an initiative. It is an essential tool at the initiation level of entrepreneurship and as well as the running of a business. Networking with banks and business associates is called a formal network, whereas networking with friends and previous employers is called an informal network. Birley (1985) added that formal networks are rarely used by small businesses; they mostly rely on the informal network. It is equally essential for startups as well as the survival of old businesses because enterprises also rely on networking for seeking information. Lang, Calantone, and Gudmundson (1997) argued that businesses count on networks for information regarding environmental threats and opportunities. Brockhaus Sr (1980) suggested that a key to the success of entrepreneurs is that they are able to utilize their personal and professional networks to reach the resources and enhance their capabilities better than their competitors. Sharma and Chrisman (1999) felt that alliances and networks of firms help them in exploring new ideas and innovation. Anderson and Jack (2002) also acknowledged that networking is beneficial to both individuals and firms in wide-ranging matters, such as creating an identity (Hindle, 2010) and awareness of opportunities and technologies encompassing both academia and the corporate sector (Owen-Smith \& Powell, 2004). Networking also helps investors in identifying new firms for financing (Steijvers, Voordeckers, \& Vanhoof, 2010). It 
reduces cost by creating a trust (Doloreux \& Parto, 2005). Networking of entrepreneurs and mentors helps in getting guidance and sharing skills (Stam \& Spigel, 2016). Access to a pool of talented workers, suppliers, customers, and new markets can also be achieved through networking (Spigel, 2017). Additionally, networking creates an informal social relationship that helps in enhancement of collective learning capacity (Doloreux \& Parto, 2005), which creates an entrepreneur's ability to formulate competition for global strategies (Vasilchenko \& Morrish, 2011). Finally, it helps businesses in innovativeness and growth (Slotte-Kock \& Coviello, 2010). In the recent past, many studies were conducted to analyze the effect of economic freedom on entrepreneurship. Sobel, Clark, and Lee (2007) conducted a study on the OECD countries, establishing that there is a direct and statistically significant relationship between economic freedom and overall entrepreneurial activities in a country. Various studies have suggested intellectual property rights, access to finance, labor, legal framework, ease of international trading, and credit regulation as the dimensions of economic freedom (Björklund, Jäntti, \& Solon, 2007; Fuentelsaz, González, Maícas, \& Montero, 2015).

\section{Mentorship}

Due to tremendous competition, nothing can be achieved without acquiring proper skills, leading to the significant roles of mentors, startup trainers, soft skills developers, and business planning institutes. Mentoring programs conducted by current entrepreneurs and professionals play a catalytic role in the success of startups (Khan, 2016). Motivating entrepreneurs through success stories and moral support plays a pivotal role in continuing their struggle.

From the above literature, we have identified the following dimensions that constitute the entrepreneurial ecosystem:

These factors can be grouped, keeping in view their relevance, and each group can be given a name. This grouping can help not only to sort out the overlapping factors but also to devise better policy.

\section{Methodology}

The purpose of this paper is to prioritize the dimensions and sub-dimensions of EES to make an index. To achieve this end, we divided the entire process into three phases:

\section{Identification}

In this phase, we reviewed the literature on the factors affecting the entrepreneurial ecosystem and identified 63 factors representing Entrepreneurial Ecosystems. These are listed in Table 1.

\section{Selection}

Since identified factors were too numerous to be processed for AHP analysis, we picked the relevant dimensions/sub-dimensions with the help of a survey. A 3-point Likert scale questionnaire, with responses ranging from 1 to 3 (where 1 denotes not important, 2 somewhat important, and 3 very important), was used for this survey following the procedure adopted by (Mubarik et al., 2018). The questionnaire consisted of two parts; part 1 of the questionnaire contained demographic questions, and part 2 
Table 1 Dimensions of the entrepreneurial ecosystem

\begin{tabular}{|c|c|}
\hline Dimensions & Source(s) \\
\hline Academia-industry collaborative initiatives & Cohen (2006); Isenberg (2010); Rahatullah (2013) \\
\hline Alliance & Sharma \& Chrisman, (1999) \\
\hline Angel investor & Van Praag and Versloot (2007) \\
\hline Building infrastructure & Van Praag and Versloot (2007) \\
\hline Capital structure & Isenberg (2010); Cohen (2006) \\
\hline Collaboration among the industries & Rahatullah (2013) \\
\hline Commercial banks & Isenberg (2010) \\
\hline Communities from local area & Mokry (1988) \\
\hline Communities individual & Kao (1993) \\
\hline Consultant for the legal affair & Van Praag and Versloot (2007) \\
\hline Consultant of marketing & Van Praag and Versloot (2007) \\
\hline Consulting firms & Rahatullah (2013) \\
\hline Culture & Isenberg (2010) \\
\hline Developmental role of govt & Suresh and Ramraj (2012) \\
\hline Distributing processes & Van De Ven (1993) \\
\hline Early customers. & Isenberg (2010) \\
\hline Ease of immigration for foreigners & Dana (1999) \\
\hline Economic clusters & Isenberg (2010) \\
\hline Educational institution & Cohen (2006); Isenberg (2010); Rahatullah (2013) \\
\hline Environmental support & Suresh and Ramraj (2012) \\
\hline Existence of local markets & Van Praag and Versloot (2007) \\
\hline Financial incentives & Dana (1990); Isenberg (2010); Penning (1982) \\
\hline Financial support & Suresh and Ramraj (2012) \\
\hline Government support & Suresh and Ramraj (2012); Isenberg (2010); (Szabo 2006) \\
\hline Governmental institutions for entrepreneurial finance & Hindle (2010) \\
\hline Governmental skill enhancement programs & Suresh and Ramraj (2012) \\
\hline Human resource & Isenberg (2010) \\
\hline Incubation centers & Rahatullah (2013), Van Praag and Versloot (2007) \\
\hline Industrial clusters & Cohen (2006) \\
\hline Industrial infrastructure & Van De Ven (1993) \\
\hline Industrial networks & Van De Ven (1993) \\
\hline Industrial trainings & Van De Ven (1993) \\
\hline Infrastructure & Isenberg (2010) \\
\hline Intellectual property rights & Rahatullah (2013) \\
\hline International donors role & Rahatullah (2013) \\
\hline IT infrastructure & Rahatullah (2013) \\
\hline Leadership & Isenberg (2010) \\
\hline Lobbying firms & Van Praag and Versloot (2007) \\
\hline Local supplier market & Van Praag and Versloot (2007) \\
\hline Management consultant & Van Praag and Versloot (2007) \\
\hline Market & Isenberg (2010) \\
\hline Marketing facilities & Van De Ven (1993) \\
\hline Mega urban centers & Penning (1982) \\
\hline Mentoring programs & Chautin (2011) \\
\hline
\end{tabular}


Table 1 Dimensions of the entrepreneurial ecosystem (Continued)

\begin{tabular}{|c|c|}
\hline Dimensions & Source(s) \\
\hline Micro finance banks & Chautin (2011) \\
\hline Moral support & Suresh and Ramraj (2012) \\
\hline Network formal as well as informal & Cohen (2006) \\
\hline Network informally & Birley (1985), Elfring and Hulsink (2003) \\
\hline Network support & Suresh and Ramraj (2012) \\
\hline Networking & $\begin{array}{l}\text { Anderson and Jack (2002), Doloreux and Parto (2005), } \\
\text { Klyver and Grant (2010), Owen-Smith and Powell (2004), } \\
\text { Rahatullah (2010), Stam and Spigel (2016) }\end{array}$ \\
\hline NGOs & Hindle (2010) \\
\hline Non-financial incentives & Dana (1990) \\
\hline On-the-job trainings & Mubarik (2015) \\
\hline $\begin{array}{l}\text { Policies of strategic level } \\
\text { given by government }\end{array}$ & Szabó (1995) \\
\hline Policy & Isenberg (2010) \\
\hline Pool of talented persons & Cohen (2006) \\
\hline Private equity funds & Van Praag and Versloot (2007) \\
\hline Professional & Cohen (2006) \\
\hline Professional networking & Mubarik (2015) \\
\hline $\begin{array}{l}\text { Public and private } \\
\text { sector partnership }\end{array}$ & Isenberg (2010) \\
\hline Regulatory role & Rasiah et al. (2017) \\
\hline Research center for business & Szabó (1995) \\
\hline Research culture & Rahatullah (2013) \\
\hline Resource endowment funds & Rahatullah (2013) \\
\hline Rules and regulations minimization & Dana (1990) \\
\hline Social networks & Mubarik (2016) \\
\hline Social support & Mubarik (2016) \\
\hline societal systems that admire & Vesper (1983) \\
\hline Solicitors & Van Praag and Versloot (2007) \\
\hline Success stories & Isenberg (2010) \\
\hline support services & Cohen (2006), Isenberg (2010) \\
\hline Technology support & Suresh and Ramraj (2012) \\
\hline Training facilities & Penning (1982) \\
\hline Value chain & Van de Ven (1993) \\
\hline Venture capitalist & Van Praag and Versloot (2007) \\
\hline Vocational training & Van Praag and Versloot (2007) \\
\hline
\end{tabular}

contained 63 questions related to EES. Since the focus of the study was on entrepreneurship ecosystems (EES) in Pakistan, EES experts were used to select the relevant dimensions and sub-dimensions. Thirty-seven experts were selected using the expert sampling technique, a non-probability sampling technique. This technique is a sub-case of purposive sampling in which the researcher relies on his expertise to select the sampling unit. It involves the consolidation of a sample of individuals with some ultimate experience and expertise in a particular field. The first step in expert sampling is identifying the meaning of the term "experts." We divided experts into three categories, 
namely, entrepreneurs, policy advisers, and investors. All these experts have 2 years or more of experience in doing/dealing/advising entrepreneurship in Pakistan. Table 2 illustrates the experts of the study.

\section{Prioritization}

The previous stage only identifies the relevant dimensions and sub-dimensions of EES based on the 37 selected experts. The prioritization stage assigns weight to the selected dimensions and sub-dimensions of $\mathrm{HC}$, according to their importance, using the AHP hierarchy. After establishing the hierarchy, a questionnaire consisting of bi-polar questions using the Saaty (1980) scale (Table 3) that comprises the dimensions and sub-dimensions of EES (selected in phase 2) was designed to collect the pairwise comparisons from the same 37 experts. The experts were required to compare the importance across and within dimensions. The collected data was then processed through AHP, a multi-criteria decisionmaking method developed by Saaty (1980). The AHP theory of measurement through pairwise comparisons relies on the judgments of experts to derive priority scales, which are then used to measure intangibles in relative terms. The critical concern of the AHP is to obtain consistency in the judgments. The data collected from the questionnaires are processed to structure the corresponding pairwise comparison judgment matrices (PCJM) to establish the normalized weights. The consistency index is derived from the principal Eigenvalue. The consistency ratio (CR) of each PCJM was checked to verify the consistency in the respondent's opinion. To determine the normalization of priority weights, the Expert Choice software was used.

\section{Results and discussion}

\section{Selection}

Table 4 gives the details, which are briefly explained as follows. Frequency Table 4 gives us an overview of the profiles of the respondents for this paper. Our total respondents are 37, with 26 male and the remaining 11 female. As for their qualifications, 10 are graduates, 22 masters, and five are Ph.D.

Table 5 shows the results of selection of the EES dimensions arranged in the descending order of their mean values. We computed the mean values of each dimension

Table 2 Experts sampled

\begin{tabular}{|c|c|c|}
\hline Expert group & Description & $\begin{array}{l}\text { Number } \\
\text { sampled }\end{array}$ \\
\hline Entrepreneurs & Running own entrepreneurial ventures for last 02 years & 10 \\
\hline Entrepreneurship policy advisers & $\begin{array}{l}\text { Think tanks, government official and researchers } \\
\text { advising governments for } 05 \text { years on the policy } \\
\text { development related to entrepreneurship ecosystem }\end{array}$ & 09 \\
\hline Investors & $\begin{array}{l}\text { Financer who has financed at least } 02 \text { successful } \\
\text { entrepreneurial ventures in the last } 02 \text { years }\end{array}$ & 09 \\
\hline Director ORICs & $\begin{array}{l}\text { Heads of Office of Research, Innovation, and } \\
\text { Commercialization are in universities responsible } \\
\text { for promoting business incubation centers }\end{array}$ & 09 \\
\hline Total & & 37 \\
\hline
\end{tabular}


Table 3 Saaty scale

\begin{tabular}{ll}
\hline Degree of importance & Definition \\
\hline 1 & Both dimensions are equally important \\
2 & Weakly/moderately important \\
3 & Strongly important \\
4 & Very strongly important \\
5 & Extremely important \\
$2,4,6,8$ & Intermediate values \\
\hline
\end{tabular}

Source: Saaty (1980)

and sub-dimension of EES by multiplying the percentage of respondents by the value of their responses (which are 1,2, and 3, respectively, for "important," "somewhat important," and "not important").

For the selection of the relevant dimensions, among the identified, we adopted the procedure previously followed by Mubarik et al. (2018). It uses an average of maximum mean value and minimum value as the cut-off point for selection. As per these criteria, our mean value for the dimension is 2.66 . Using this value as cut-off points, we selected 33 dimensions of EES.

Table 6 below shows that the 33 dimensions selected through mean-weighted value are grouped into eight dimensions by the characteristics. In this way, we can get the main dimensions of the entrepreneurial ecosystem: marketing, finance, human resources, infrastructure, industrial relations, learning, support, government role, social networking, and mentorship.

\section{Prioritization}

After selection and grouping, the variables and the study applied AHP to prioritize the dimensions and sub-dimensions selected. Figure 1 shows the groups with their dimensions in AHP format. The data about the prioritization of these dimensions and sub-dimensions, using the Saaty (1980) scale, were collected from 100 experts. The data were processed through the Expert Choice software for analysis. Results of the pairwise

Table 4 Demographic profile

\begin{tabular}{lc}
\hline Respondent profile & Frequency \\
\hline a. Gender & 26 \\
Male & 11 \\
Female & \\
b. Qualification & 10 \\
Graduate & 22 \\
Masters & 05 \\
Ph.D. & \\
c. Occupation & 9 \\
Investors & 9 \\
Entrepreneurship policy advisers & 9 \\
Entrepreneur & 10 \\
Director ORICs & 9 \\
\hline
\end{tabular}


Table 5 Sub-dimensions of the entrepreneurial ecosystem (EES) dimension

Academia-industry collaborative initiatives

Consulting firms

Developmental role of government

Commercial banks

Building infrastructure

Moral support

Alliance

NGOs

On-the-job trainings

Regulatory role (of government)

Industrial networks

Industrial clusters

Environmental support

Resource endowment funds

Social networks

Marketing facilities

Social support

Local supplier market

Angel investors

Existence of local markets

Success stories

Incubation center

Governmental skill enhancement programs

Micro finance banks

Industrial trainings

Governmental institutions for entrepreneurial finance

Technology support

Leadership

Vocational trainings

International donors role

IT infrastructure

Mega urban centers

Professional networking

Communities from local area

Collaboration among the industries

Capital

Communities individual

Culture

Early customers

Distributing processes

Economic clusters

Ease of immigration for foreigners

Educational institution 
Table 5 Sub-dimensions of the entrepreneurial ecosystem (EES) dimension (Continued)

\begin{tabular}{|c|c|}
\hline Financial incentives & 2.41 \\
\hline Finance & 2.41 \\
\hline Government support & 2.4 \\
\hline Government & 2.4 \\
\hline Financial support & 2.4 \\
\hline Human resource & 2.3 \\
\hline Intellectual property rights & 2.25 \\
\hline Lobbying firms & 2.23 \\
\hline Market & 2.22 \\
\hline Management consultant & 2.22 \\
\hline Mentoring programs & 2.21 \\
\hline Mega urban centers & 2.21 \\
\hline Marketing processes & 2.21 \\
\hline Moral support & 2.2 \\
\hline Networking & 2.18 \\
\hline Network support & 2.18 \\
\hline Network informally & 2.18 \\
\hline Network formal as well as informal & 2.18 \\
\hline Networks of professional & 2.15 \\
\hline societal systems that admire & 2.13 \\
\hline Non-financial incentives & 2.13 \\
\hline Policies of strategic level given by government & 2.12 \\
\hline Pool of talented persons & 2.11 \\
\hline Policy & 2.11 \\
\hline Solicitors & 2.1 \\
\hline Regulatory role & 2.1 \\
\hline Public and private sector partnership & 2.1 \\
\hline Professional & 2.1 \\
\hline Private equity funds & 2.1 \\
\hline Research center for business & 2.09 \\
\hline Research & 2.09 \\
\hline Support services & 2.08 \\
\hline Success stories & 2.08 \\
\hline Rules and regulations minimization & 2.08 \\
\hline Research culture & 2.08 \\
\hline Technology support & 2.07 \\
\hline Value chain & 2.06 \\
\hline Training facilities & 2.06 \\
\hline Venture capitalist & 2.05 \\
\hline
\end{tabular}

comparison appear in Tables 7 and 8 as pairwise comparison judgment matrices (PCJMS). Consistency ratio (CR) values of all the PCJMS demonstrate the consistency of respondents. The priority values calculated from PCJMS are summarized in Table 9. Results show that among eight dimensions of EES, human resource development (0.18) stands at the top. It is followed by finance (0.15), support (0.15), and industrial 
Table 6 Entrepreneurial ecosystem dimension

\begin{tabular}{|c|c|c|}
\hline S\# & Dimensions & Sub-dimensions \\
\hline 1 & Markets & $\begin{array}{l}\text { Industrial clusters, existence of local markets, local supplier market, mega urban } \\
\text { centers, marketing facilities }\end{array}$ \\
\hline 2 & Finance & $\begin{array}{l}\text { Angel investors, micro finance banks, commercial banks, NGOs, governmental } \\
\text { institutions for entrepreneurial finance }\end{array}$ \\
\hline 3 & $\begin{array}{l}\text { Human resource } \\
\text { development }\end{array}$ & $\begin{array}{l}\text { On-the-job trainings, industrial trainings, vocational trainings, academia-industry } \\
\text { collaborative initiatives, governmental skill enhancement programs, international } \\
\text { donors role }\end{array}$ \\
\hline 4 & Support & Moral support, social support, environmental support, technology support \\
\hline 5 & Government role & Regulatory role, developmental role \\
\hline 6 & Infrastructure & $\begin{array}{l}\text { Resource endowment funds, incubation centers, consulting firms, IT infrastructure, } \\
\text { building infrastructure }\end{array}$ \\
\hline 7 & $\begin{array}{l}\text { Industrial network } \\
\text { relationship }\end{array}$ & Alliance, industrial networks, professional networking, social networks \\
\hline 8 & Mentorship & Leadership, success stories \\
\hline
\end{tabular}

networking relations (0.15) with equal weightage. Government role (0.11), infrastructure (0.09), mentorship (0.09), and markets (0.08) are the next three. By and large, there is not a great difference in the priorities of the dimensions; however, based on ranking, results can be grouped into three categories. Human resource development (0.18) falls in the first category. In the second category, three dimensions, namely finance, support, and industrial networking, appear whereas in the last group are all of the other dimensions, namely government role, infrastructure, mentorship, and markets. The results of relative prioritization demonstrate the same picture shown by previous researchers. For example, (Mubarik et al., 2018), in their study to examine the policies for entrepreneurship development, concluded the key role of customized human resource development initiative for enhancing the survivability of new entrepreneurial ventures. They mentioned the need for an organic system for developing the human resource that fits the entrepreneurship.

Further, Xing, Liu, and Cooper (2018) mentioned the practical role of government and strong relationship management as the building blocks for a successful entrepreneurial venture. They mentioned that in many cases entrepreneurial ventures face issues which can only be solved by the government's policy interventions. These issues can be developmental issues like availability of funds at a low-interest rate, training of entrepreneurs by the government, providing marketing facilities by the government and operational issues like conflict resolutions, etc. Whatever the case, government can be

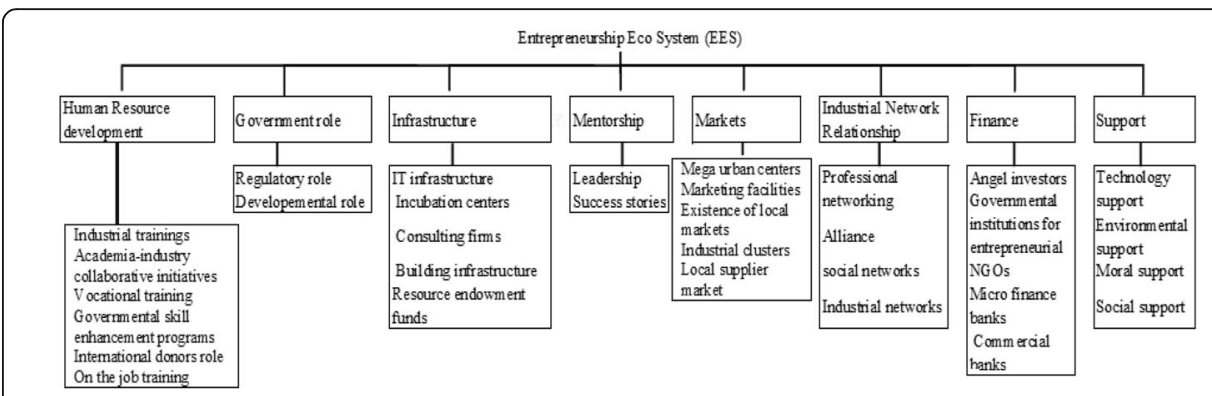

Fig. 1 AHP hierarchy 
Table 7 Pairwise comparison judgment matrices (PJMS) of dimensions

\begin{tabular}{|c|c|c|c|c|c|c|c|}
\hline & (2) & (3) & (4) & (5) & (6) & (7) & (8) \\
\hline Human resource development (1) & 1.64 & 1.03 & 1.29 & 1.74 & 1.25 & 1.17 & 2.29 \\
\hline Finance (2) & 1 & 1.56 & 1.23 & 1.96 & 1.11 & 1.39 & 1.65 \\
\hline Support (3) & & 1 & 1.12 & 1.09 & 0.89 & 1.25 & 1.02 \\
\hline Industrial network relationship (4) & & & 1 & 1.41 & 0.95 & 1.11 & 1.14 \\
\hline Government role (5) & & & & 1 & 0.77 & 1.41 & 1.08 \\
\hline Infrastructure (6) & & & & & 1 & 1.23 & 1.51 \\
\hline Mentorship (7) & & & & & & 1 & 1.73 \\
\hline \multirow[t]{2}{*}{ Markets (8) } & & & & & & & 1 \\
\hline & & & & & & $C R=$ & \\
\hline
\end{tabular}

instrumental in helping entrepreneurs compete for such issues effectively. Likewise, there is a strong consensus of researchers on the critical role of finance on entrepreneurial ventures. Despite differences in the level of prioritization, all dimensions possess specific roles in the process of forming an effective entrepreneurial ecosystem and cannot be excluded (Fig. 2). Further, looking into the prioritizations of the sub-dimensions of EES will help operationalize the findings.

Among the sub-dimensions of human resource development, industrial training (0.25) appears at the top of the list, followed by academia-industry collaborative initiatives (0.21), vocational training (0.19), governmental skill enhancement programs (0.18), with marginal differences, whereas international donors role (0.09) and on-thejob training (0.08) appear at the bottom of the list with considerable low weightage. This prioritization shows the critical role of industrial training conducted by the government or NGOs to equip potential entrepreneurs with industry-specific technical skills. The importance of such initiatives has also previously been proclaimed by numerous research studies (e.g., Ateljevic \& Gallagher, 2017).

Among the dimensions of finance, angel investors (0.30) possesses the highest priority, followed by governmental institutions for entrepreneurial finance (0.24), NGOs (0.18), and commercial banks (0.11). Further, in the dimensions of support (0.15), technological support (0.30) appears to be the first, followed by environmental support (0.25), moral support (0.24), and social support (0.21). These results can be explained in the light of extant research recommendations where the need for research and development has been emphasized to drive innovation and research culture. Van Praag and Versloot (2007) highlighted that enterprises require funds to kick-start their ventures. So there is a need for angel investors, governmental institutions for entrepreneurial finance, NGOs, and commercial banks. They also emphasized the role of environmental, technological, social, and moral support as critical factors in bolstering entrepreneurial culture.

Likewise, comparisons of the dimensions of industrial networking relationships reveal that professional networking $(0.30)$ has the highest priority, followed by alliances $(0.25)$, social networks (0.24), and industrial networks (0.21). Further, the two dimensions of government role and regulatory role $(0.60)$ have relatively higher weightage as compared to the developmental role (0.40). The comparisons of the following dimensions, i.e., infrastructure, demonstrate the highest priority of IT infrastructure (0.31), followed by incubation centers $(0.22)$, building infrastructure (0.18), consulting firms $(0.18)$, and resource endowment funds (0.11). 
Table 8 Pairwise comparison judgment matrices (PJMS) of sub-dimensions

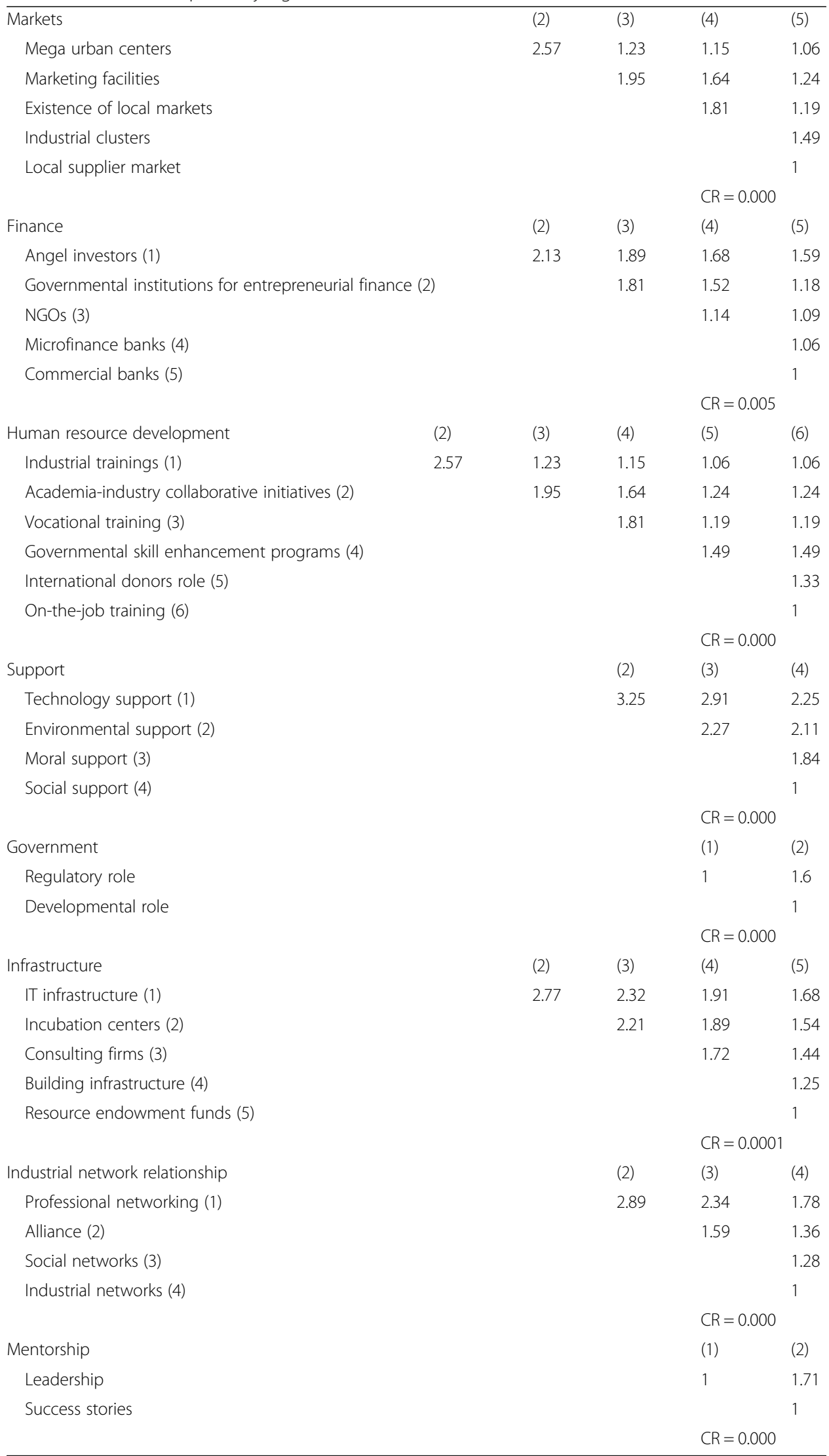


Table 9 Entrepreneurial ecosystem index

\begin{tabular}{|c|c|c|c|c|}
\hline Dimensions & LW & Sub-dimensions & LW & GW \\
\hline \multirow[t]{5}{*}{ Markets } & \multirow[t]{5}{*}{0.08} & Industrial clusters & 0.13 & 0.010 \\
\hline & & Existence of local markets & 0.17 & 0.014 \\
\hline & & Local supplier market & 0.11 & 0.009 \\
\hline & & Mega urban centers & 0.33 & 0.026 \\
\hline & & Marketing facilities & 0.26 & 0.021 \\
\hline \multirow[t]{5}{*}{ Finance } & \multirow[t]{5}{*}{0.15} & Angel investors & 0.3 & 0.045 \\
\hline & & Micro finance banks & 0.17 & 0.026 \\
\hline & & Commercial banks & 0.11 & 0.017 \\
\hline & & NGOs & 0.18 & 0.027 \\
\hline & & Governmental institutions for entrepreneurial finance & 0.24 & 0.036 \\
\hline \multirow[t]{6}{*}{ Human resource development } & \multirow[t]{6}{*}{0.18} & On-the-job training & 0.08 & 0.014 \\
\hline & & Industrial trainings & 0.25 & 0.045 \\
\hline & & Vocational trainings & 0.19 & 0.034 \\
\hline & & Academia-industry collaborative initiatives & 0.21 & 0.038 \\
\hline & & Governmental skill enhancement programs & 0.18 & 0.032 \\
\hline & & International donors role & 0.09 & 0.016 \\
\hline \multirow[t]{4}{*}{ Support } & \multirow[t]{4}{*}{0.15} & Moral support & 0.24 & 0.036 \\
\hline & & Social support & 0.21 & 0.032 \\
\hline & & Environmental support & 0.25 & 0.038 \\
\hline & & Technology support & 0.3 & 0.045 \\
\hline \multirow[t]{2}{*}{ Government role } & \multirow[t]{2}{*}{0.11} & Regulatory role & 0.6 & 0.066 \\
\hline & & Developmental role & 0.4 & 0.044 \\
\hline \multirow[t]{5}{*}{ Infrastructure } & \multirow[t]{5}{*}{0.09} & Resource endowment funds & 0.11 & 0.010 \\
\hline & & Incubation centers & 0.22 & 0.020 \\
\hline & & Consulting firms & 0.18 & 0.016 \\
\hline & & IT infrastructure & 0.31 & 0.028 \\
\hline & & Building infrastructure & 0.18 & 0.016 \\
\hline \multirow[t]{4}{*}{ Industrial network relationship } & \multirow[t]{4}{*}{0.15} & Alliance & 0.25 & 0.038 \\
\hline & & Industrial networks & 0.21 & 0.032 \\
\hline & & Professional networking & 0.3 & 0.045 \\
\hline & & Social networks & 0.24 & 0.036 \\
\hline \multirow[t]{2}{*}{ Mentorship } & \multirow[t]{2}{*}{0.09} & Leadership & 0.62 & 0.056 \\
\hline & & Success stories & 0.38 & 0.034 \\
\hline
\end{tabular}

Comparing dimensions of markets shows that mega urban centers (0.33), followed by marketing facilities (0.26), the existence of local markets (0.17), industrial cluster (0.13), and local supplier market (0.11). Among the dimensions of mentorship, leadership (0.62) has a higher priority as compared to success stories (0.38).

Further, the comparisons of global weights can portray another important dimension. Global weights show the relative priority of sub-dimensions in the goal. Among 33 subdimensions, the regulatory role of the government appears at the top, followed by leadership and angel investors. Local supplier market and resource endowment funds possessed the least global weights comparatively. 


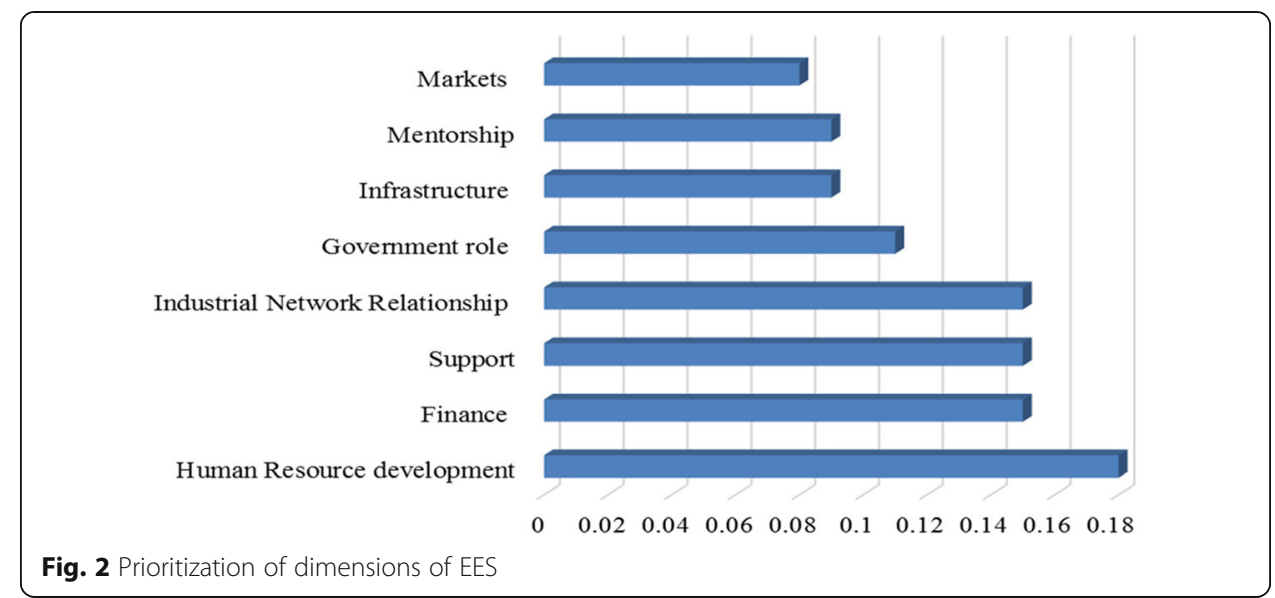

In summary, human resource development, finance, support, and industrial network relationship are the most critical dimensions to be examined while forming the entrepreneurial ecosystem. In sub-dimensions, the regulatory role of government, leadership, angel investors, industrial training, technology support, and professional networking are the most important to form an EES. Interestingly, among most crucial sub-dimensions, leadership stands at the top, followed by talent and collaboration among the industry. Based on the results, the study was able to overcome some of the limitations of the past studies by identifying the essential dimensions and sub-dimensions of EES. These dimensions can be tested and verified against different environments and prioritization can be further developed so that specific entrepreneurial development policies can be formulated based on the specific industrial or sectorial needs. Table 9 reports the derivation of the composite index known as the EES. It avoids the biases of using any single measure or a few particular measures with weights as reported in previous studies (Fig. 3).

\section{Conclusion and implications}

The objective of the study was to prioritize the selected dimensions and sub-dimensions of the entrepreneurial ecosystem. Eight dimensions and their 33 sub-dimensions were selected through preliminary analysis and literature review. By applying AHP, the study prioritized the selected dimensions and sub-dimensions. The results of prioritization showed human resource development as the most critical dimension of EES. Likewise, finance, support, and industrial network relationship appear to be equally crucial after HRD. Among sub-dimensions, the regulatory role of the government, leadership, angel investors, and industrial training appear to be at the top of the list, followed by the remainder. It is important to mention that this study

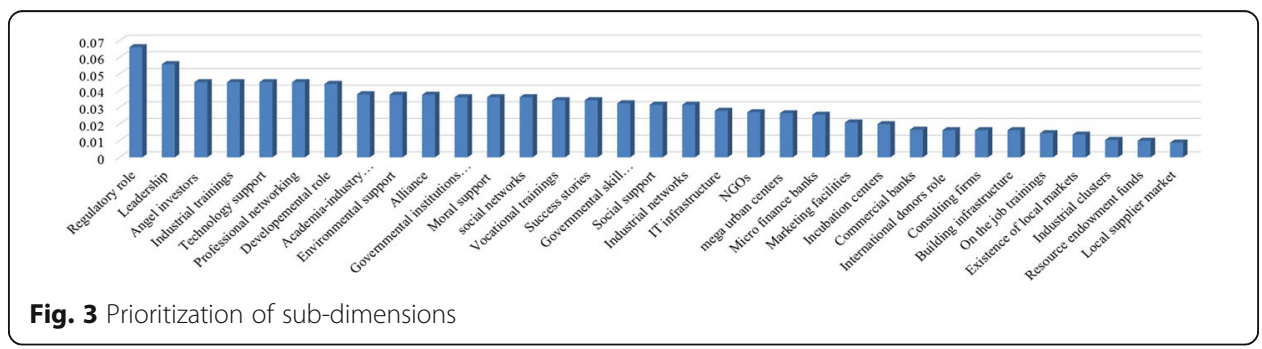


was not industry-specific, and we consider these factors equally applicable in all industries.

Although the study aims to prioritize the dimensions and sub-dimensions of EES, it requires some key issues to be addressed before devising any policy for promoting EES. First of all, the dimensions of the entrepreneurial ecosystem do not take into account the heterogeneity among its actors, focus, and scale thus creating difficulty in devising an optimal policy which can be instrumental in improving the performance of an entrepreneurial ecosystem (Brown and Mason 2017). The second point of concern is performance within EES. It is clear that digital technologies ascending through EES can be instrumental in decreasing the transactional costs among actors and organizations. It is also imperative that the performance of an EES can be defined by its ability to explore the frontiers of new knowledge. Nevertheless, the answer to the question "what does performance mean in an entrepreneurial ecosystem?" is still ambivalent and very open. The issues mentioned above set directions for future researches and require an in-depth analysis in order to devise optimal policy for improving EES. Since the results of the study are primarily based upon the expert opinions, the results of the study may be improved by increasing the number of experts. Future studies can triangulate the results of this study by increasing the sample size.

\section{Abbreviations \\ AHP: Analytical hierarchal process; DCs: Developed countries; EES: Entrepreneurial ecosystem; HRD: Human resources development; LDCs: Less developed countries}

\section{Acknowledgements}

Nil

\section{Authors' contributions}

SM, the first author, conceived the idea and helped in writing the "Introduction" section. He also collected the data from the respondents and analyzed the data by applying the analytical hierarchal process (AHP). SM, the second author, wrote the literature review of the study. He also helped in writing implications of the study. NN, the third author, wrote the conclusion and implications of the study. She also helped in writing the literature review. All authors read and approved the final manuscript.

Funding

We have not taken any kind of funding for this research study.

\section{Availability of data and materials}

Data and material are available upon request.

Competing interests

The authors declare that they have no competing interests.

\section{Author details}

'Department of Management Sciences, Mohammad Ali Jinnah University, Karachi, Pakistan. ${ }^{2}$ Taylor's Business School, Taylor's University, Subang Jaya, Malaysia.

Received: 7 June 2019 Accepted: 25 July 2019

Published online: 25 August 2019

\section{References}

Abid, A. (2007). The world's largest economy is in worse shape than it cares to admit. Noticias Financiers, 1.

Allesina, S., Azzi, A., Battini, D., \& Regattieri, A. (2010). Performance measurement in supply chains: New network analysis and entropic indexes. International Journal of Production Research, 48(8), 2297-2321.

Anderson, A. R., \& Jack, S. L. (2002). The articulation of social capital in entrepreneurial networks: A glue or a lubricant? Entrepreneurship \& Regional Development, 14(3), 193-210.

Anwar ul Haq, M., Usman, M., Hussain, N., \& Anjum, Z.-Z. (2014). Entrepreneurial activity in China and Pakistan: A GEM data evidence. Journal of Entrepreneurship in Emerging Economies, 6(2), 179-193.

Ateljevic, J., \& Gallagher, D. (2017). Building institutional, economic and social capacities: The role of NGOs in the context of Bosnia-Herzegovina \& Serbia. Tourism and entrepreneurship. In J. Ateljevic \& S. J. Page (Eds.), Tourism and entrepreneurship: International perspectives. Oxford: Butterworth-Heinemann Ltd.. 
Bhawe, N., \& Zahra, S. A. (2017). Inducing heterogeneity in local entrepreneurial ecosystems: The role of MNEs. Small Business Economics, 52(2), 437-454.

Birley, S. (1985). The role of networks in the entrepreneurial process. Journal of Business Venturing, 1(1), 107-117.

Björklund, A., Jäntti, M., \& Solon, G. (2007). Nature and nurture in the intergenerational transmission of socioeconomic status: Evidence from Swedish children and their biological and rearing parents. The B.E. Journal of Economic Analysis \& Policy, 7(2), 1935-1682.

Boyd, B. K., Dess, G. G., \& Rasheed, A. M. (1993). Divergence between archival and perceptual measures of the environment: Causes and consequences. Academy of Management Review, 18(2), 204-226.

Brockhaus, R. H., Sr. (1980). Risk taking propensity of entrepreneurs. Academy of Management Journal, 23(3), 509-520.

Brown, R., \& Mason, C. (2017). Looking inside the spiky bits: a critical review and conceptualisation of entrepreneurial ecosystems. Small Business Economics, 49(1), 11-30.

Bygrave, W., Hay, M., Ng, E., \& Reynolds, P. (2003). Executive forum: A study of informal investing in 29 nations composing the Global Entrepreneurship Monitor. Venture Capital: An International Journal of Entrepreneurial Finance, 5(2), 101-116.

Campbell, C. A. (1992). A decision theory model for entrepreneurial acts. Entrepreneurship Theory and Practice, 17(1), 21-27.

Chautin, J. (2011). Biz Voices: Vets turn to entrepreneurship: Mentoring program helps young veterans start small businesses. Jobless rate for military a factor in transition. The Atlanta Journal, D2.

Cohen, B. (2006). Sustainable valley entrepreneurial ecosystems. Business Strategy and the Environment, 15(1), 1-14.

Dana, L. P. (1990). Saint Martin/Sint Maarten: A case study of the effects of culture on economic development. Journal of Smalt Business Management, 25(4), 91-98.

Dana, L. P. (1999). Business and entrepreneurship in Bosnia-Herzegovina. Journal of Business \& Entrepreneurship, 11(2), 105118.

Doloreux, D., \& Parto, S. (2005). Regional innovation systems: Current discourse and unresolved issues. Technology in Society, 27(2), 133-153.

Elfring, T., \& Hulsink, W. (2003). Networks in entrepreneurship: The case of high-technology firms. Small Business Economics, 21(4), 409-422.

Etzkowitz, H., Webster, A., Gebhardt, C., \& Terra, B. R. C. (2000). The future of the university and the university of the future: Evolution of ivory tower to entrepreneurial paradigm. Research Policy, 29(2), 313-330.

Fellnhofer, K., \& Mueller, S. (2018). "I want to be like you!": The influence of role models on entrepreneurial intention. Journal of Enterprising Culture, 26(02), 113-153.

Frank, H., Lueger, M., \& Korunka, C. (2007). The significance of personality in business start-up intentions, start-up realization and business success. Entrepreneurship \& Regional Development, 19(3), 227-251.

Fuentelsaz, L., González, C., Maícas, J. P., \& Montero, J. (2015). How different formal institutions affect opportunity and necessity entrepreneurship. BRQ Business Research Quarterly, 18(4), 246-258.

Hindle, K. (2010). How community context affects entrepreneurial process: A diagnostic framework. Entrepreneurship and Regional Development, 22(7-8), 599-647.

lansiti, M., \& Levien, R. (2004). The keystone advantage: What the new dynamics of business ecosystems mean for strategy, innovation, and sustainability. Boston: Harvard Business Press.

Isenberg, D. J. (2010). The Big Idea: How to start an entrepreneurial revolution. Harvard Business Review, 88(6), 41-50.

Ivanov, D., \& Dolgui, A. (2018). Low-certainty-need (LCN) supply chains: A new perspective in managing disruption risks and resilience. International Journal of Production Research, 1-18. https://www.tandfonline.com/doi/full/10.1080/00207543.201 8.1521025

Johannisson, B. (2017). Networking and entrepreneurial growth. The Blackwell Handbook of Entrepreneurship (368-386), Blackwell Publishers Ltd.

Kao, J. (1993). The worldwide web of Chinese business. Harvard Business Review, 24-36.

Kautonen, T., van Gelderen, M., \& Fink, M. (2015). Robustness of the theory of planned behavior in predicting entrepreneurial intentions and actions. Entrepreneurship Theory and Practice, 39(3), 655-674.

Khan, M. R. (2016). Entrepreneurship ecosystem evolution strategy of Saudi Arabia. International Entrepreneurship| Przedsiębiorczość Międzynarodowa, 2(2), 67-92.

Klyver, K., \& Grant, S. (2010). Gender differences in entrepreneurial networking and participation. International Journal of Gender and Entrepreneurship, 2(3), 213-227.

Korunka, C., Frank, H., Lueger, M., \& Mugler, J. (2003). The entrepreneurial personality in the context of resources, environment, and the startup process-a configurational approach. Entrepreneurship Theory and Practice, 28(1), 23-42.

Krueger, N. F. (2017). Entrepreneurial intentions are dead: Long live entrepreneurial intentions. In M. Brännback \& A. Carsrud (Eds.), Revisiting the entrepreneurial mind. International studies in entrepreneurship (Vol. 35). Cham: Springer.

Lang, J. R., Calantone, R. J., \& Gudmundson, D. (1997). Small firm information seeking as a response to environmental threats and opportunities. Journal of Small Business Management, 35(1), 11-23.

Lee, S. M., \& Peterson, S. J. (2000). Culture, entrepreneurial orientation, and global competitiveness. Journal of World Business, 35(4), 401-416.

Lehner, O. M., \& Harrer, T. (2019). Crowd funding revisited: A neo-institutional field-perspective. Venture Capital, 21(1), 75-96.

Malen, J., \& Marcus, A. A. (2017). Promoting clean energy technology entrepreneurship: The role of external context. Energy Policy, 102(3), 7-15.

Man, T. W., Lau, T., \& Chan, K. (2002). The competitiveness of small and medium enterprises: A conceptualization with focus on entrepreneurial competencies. Journal of Business Venturing, 17(2), 123-142.

Mokry, B. W. (1988). Entrepreneurship and public policy. New York: Quorum Books.

Mubarik, M. S. (2015). Human capital and performance of small \& medium manufacturing enterprises: A study of Pakistan (Doctoral dissertation, University of Malaya). Accessed from: http://studentsrepo.um.edu.my/6573/1/Shujaat_Mubarik_Thesis_Final_ Submission_.pdf (Accessed 24 Feb 2019).

Mubarik, M. S., Chandran, V., \& Devadason, E. S. (2018). Measuring human capital in small and medium manufacturing enterprises: What matters? Social Indicators Research, 137(2), 605-623.

Mubarik, S., Chandran, V. G. R., \& Devadason, E. S. (2016). Relational capital quality and client loyalty: firm-level evidence from pharmaceuticals, Pakistan. The learning organization, 23(1), 43-60. 
Nabi, G., Liñán, F., Fayolle, A., Krueger, N., \& Walmsley, A. (2017). The impact of entrepreneurship education in higher education: A systematic review and research agenda. Academy of Management Learning \& Education, 16(2), 277-299.

Naghavi N., Mubarak M.S. (2019) Negotiating with Managers from South Asia: India, Sri Lanka, and Bangladesh. In: Khan M., Ebner N. (eds) The Palgrave Handbook of Cross-Cultural Business Negotiation. Palgrave Macmillan, Cham

Oosterbeek, H., Van Praag, M., \& ljsselstein, A. (2010). The impact of entrepreneurship education on entrepreneurship skills and motivation. European Economic Review, 54(3), 442-454.

Owen-Smith, J., \& Powell, W. W. (2004). Knowledge networks as channels and conduits: The effects of spillovers in the Boston biotechnology community. Organization Science, 15(1), 5-21.

Pennings, J. M. (1982). Organizational birth frequencies: An empirical investigation. Administrative Science Quarterly, 27, 120-144.

Prahalad, C. (2005). The fortune at the bottom of the pyramid: eradicating poverty through profits, Saddle River. NJ: Wharton School Publishing/Pearson.

Rahatullah Khan, M. (2013). Mapping entrepreneurship ecosystem of Saudi Arabia. World Journal of Entrepreneurship, Management and Sustainable Development, 9(1), 28-54

Rahatullah, M. (2010). Achieving competitive advantage in hybrid relationship businesses. UK: Lambert Academic Publishing.

Rasiah, R., Mubarik, S., \& Yap, X. S. (2017). Financing Technological Upgrading in East Asia. The Lahore Journal of Economics, 22, 153-182.

Romero-Martínez, A. M., \& Montoro-Sánchez, Á. (2008). How clusters can encourage entrepreneurship and venture creation. Reasons and advantages. International Entrepreneurship and Management Journal, 4(3), 315-329.

Saaty, T. (1980). The analytic hierarchy process. New York: McGraw-Hill.

Segura, E. (1988). Industrial, trade and financial sector policies to foster private enterprises in developing-countries. Columbia Journal of World Business, 23(1), 19-26.

Shapero, A., \& Sokol, L. (1982). The social dimensions of entrepreneurship. Encyclopedia of entrepreneurship, 72-90.

Sharma, P., \& Chrisman, J. (1999). Entrepreneurship theory and practice, toward a reconciliation of the definitional issues in the field of corporate entrepreneurship. Journal of Business and Management, 20(9), 31-41.

Slotte-Kock, S., \& Coviello, N. (2010). Entrepreneurship research on network processes: A review and ways forward. Entrepreneurship Theory and Practice, 34(1), 31-57.

Smith, N. R. (1967). The entrepreneur and his firm: The relationship between type of man and type of company. Occasional Papers, Bureau of Business and Economic Research, Michigan State University, 109.

Smith, N. R., \& Miner, J. B. (1983). Type of entrepreneur, type of firm, and managerial motivation: Implications for organizational life cycle theory. Strategic Management Journal, 4(4), 325-340.

Sobel, R. S., Clark, J., \& Lee, D. R. (2007). Freedom, barriers to entry, entrepreneurship, and economic progress. The Review of Austrian Economics, 20(4), 221-236.

Spigel, B. (2017). The relational organization of entrepreneurial ecosystems. Entrepreneurship Theory and Practice, 41(1), 49-72.

Stam, F., \& Spigel, B. (2016). Entrepreneurial ecosystems. USE Discussion Paper Series, 16(13), 1-15.

Steijvers, T., Voordeckers, W., \& Vanhoof, K. (2010). Collateral, relationship lending and family firms. Small Business Economics, 34(3), 243-259.

Stuart, T. E., \& Sorenson, O. (2005). Social networks and entrepreneurship. In Handbook of entrepreneurship research (pp. 233252). Springer, Boston

Suresh, J., \& Ramraj, R. (2012). Entrepreneurial ecosystem: Case study on the influence of environmental factors on entrepreneurial success. European Journal of Business and Management, 4(16), 95-101.

Szabó, A. (1995). The role of small and medium-sized enterprises in countries is transition and how to promote them. In ECE Advisory Workshop on Industrial Restructuring.

Szabó, A. (2006). Business incubation as an element of business service institution and SME development infrastructure for the creation of new enterprises in CITs. ERENET, Budapest.-2006-14C.

Valliere, D., \& Peterson, R. (2009). Entrepreneurship and economic growth: Evidence from emerging and developed countries. Entrepreneurship \& Regional Development, 21(5-6), 459-480.

Van de Ven, H. (1993). The development of an infrastructure for entrepreneurship. Journal of Business Venturing, 8(3), 211-230.

Van Praag, C. M., \& Versloot, P. H. (2007). What is the value of entrepreneurship? A review of recent research. Small Business Economics, 29(4), 351-382.

Vasilchenko, E., \& Morrish, S. (2011). The role of entrepreneurial networks in the exploration and exploitation of internationalization opportunities by information and communication technology firms. Journal of International Marketing, 19(4), 88-105.

Vesper, K. H. (1983). Entrepreneurship and national policy (Vol. 3). Chicago: Walter E. Heller International Corporation Institute for Small Business.

Wiklund, J., Davidsson, P. and Delmar, F. (2008), Entrepreneurship and Growth of Firm, Edward Elgar Publishing.

Williams, C. C., \& Shahid, M. S. (2016). Informal entrepreneurship and institutional theory: Explaining the varying degrees of (in)formalization of entrepreneurs in Pakistan. Entrepreneurship \& Regional Development, 28(2), 1-25.

Xing, Y., Liu, Y., \& Cooper, S. C. L. (2018). Local government as institutional entrepreneur: Public-private collaborative partnerships in fostering regional entrepreneurship. British Journal of Management, 29(4), 670-690.

\section{Publisher's Note}

Springer Nature remains neutral with regard to jurisdictional claims in published maps and institutional affiliations. 